\title{
Sites of Serum a-Fetoprotein Synthesis in the Human and in the Rat*
}

\author{
David Gitlin $\dagger$ and Mary Boesman \\ (From the Department of Pediatrics of the University of Pittsburgh School of Medicine and \\ the Children's Hospital of Pittsburgh, Pittsburgh, Pa.)
}

\begin{abstract}
Summary. Selected tissues from human embryos of 6 to 9 weeks' gestation, from rat fetuses of 15 days' gestation, and from rats 2 days of age were incubated with ${ }^{14} \mathrm{C}$-labeled amino acids. Immunoelectrophoresis of the culture fluid after incubation, using rabbit antisera against human and rat fetal serum proteins, followed by radioautography revealed that: 1) Radioactive $\alpha$-fetoprotein was present in cultures of human liver, rat liver, and rat yolk sac, but not in cultures of human or rat brain, lung, heart, kidney, intestines, skeletal muscle, skin, or placenta; human yolk sac was not studied. 2) Radioactive transferrin was also present in rat yolk sac cultures, and the same protein was found in rat liver cultures as well. 3) Rat liver and rat placenta cultures both produced radioactive serum $R \alpha_{2}$-globulin.

Serum $\alpha$-fetoprotein concentrations in the rat declined abruptly after birth to approximately half of the prenatal level by 2 to 3 days of age, in accord with the loss of the fetal membranes at delivery; the $\alpha$-fetoprotein level then remained relatively constant until the rat was 6 to 8 days of age, after which synthesis of the protein was increasingly suppressed.
\end{abstract}

\section{Introduction}

At some time before the seventh week of gestation, an $\alpha$-globulin, which has been termed $\alpha$-fetoprotein, appears in the serum of the human embryo (1). Synthesis of the protein increases rapidly, and by 13 weeks' gestation serum concentrations of approximately $300 \mathrm{mg}$ per $100 \mathrm{ml}$ are attained. The total amount of serum $\alpha$-fetoprotein synthesized by the conceptus continues to increase until 20 weeks' gestation, but the serum concentration of the protein decreases after the thirteenth week, due to a rate of fetal growth greater than the relative increase in the amount of $\alpha$-fetoprotein synthesized. After 20 weeks' gestation, total $\alpha$-fetoprotein synthesis becomes relatively constant until

\footnotetext{
* Submitted for publication December 5, 1966; accepted March 10, 1967.

Supported by grants HD-00652 and HD-01031 from the National Institute of Child Health and Human Development.

$\dagger$ Address requests for reprints to Dr. David Gitlin, Dept. of Pediatrics, Children's Hospital of Pittsburgh, Pittsburgh, Pa. 15213.
}

it is sharply curtailed either at birth or during the 2 to 4 weeks preceding birth, whether the infant is full-term or is born prematurely (1). The protein disappears from the serum of the newborn infant with a half-life of approximately 3.5 days. Serum $\alpha$-fetoprotein is not found beyond the neonatal period, and it is not present in the serum of the pregnant woman $(2-11)$.

The present report is an examination of the sites of synthesis of $\alpha$-fetoprotein, in part based upon studies of the human fetus, but for the most part based upon studies in the rat, a species that synthesizes an $\alpha$-fetoprotein analogous to that in the human (12-15).

\section{Methods}

Incubation of human and rat tissues with amino acids${ }^{14} C$. Tissues from three human embryos ${ }^{1}$ were studied; the embryos were presumably normal, the indications for

${ }^{1}$ Made available through the cooperation of $\mathrm{Dr}$. Valdemar Madsen of the Københavns Amts Sygehus, Gentofte, Denmark, and Dr. Norio Fujiki of the Kyoto Prefectural University of Medicine, Kyoto, Japan. 
each abortion being psychological rather than physical. Two of the embryos were delivered virtually intact per vagina by dilatation followed by forceps extraction, and the third was delivered within its membranes by cesarean section. The embryos measured 20,25 , and $43 \mathrm{~mm}$ in crown-rump length and were estimated to be 6,7 , and 9 weeks' gestation, respectively, using Streeter's horizons (16) and Patten's data (17), values that agreed well with the date of each mother's last menstrual period. The tissues were obtained immediately after delivery of the embryo and minced with scissors, and amounts up to $50 \mathrm{mg}$ were placed in tubes with $2 \mathrm{ml}$ of Eagle's basal medium in Hank's solution ${ }^{2}$ containing $5 \%$ horse serum and $2 \mu \mathrm{c}$ of either glycine- $2-{ }^{14} \mathrm{C}$ or L-phenylalanine- $3-{ }^{14} \mathrm{C}$, each with a specific activity of $1 \mathrm{mc}$ per mmole. Cultures of liver, skin, skeletal muscle, brain, lung, and placenta were prepared in duplicate from each embryo, but only single cultures of heart, stomach, intestines, and umbilical cord were prepared. The tubes were incubated at $37^{\circ} \mathrm{C}$ for 9 to 16 hours, and the cultures were then centrifuged; the supernatants were collected, dialyzed against distilled water, and lyophilized, and each was redissolved in $0.1 \mathrm{ml}$ of $0.1 \mathrm{M} \mathrm{NaCl}$.

The rats used in this study were albino rats derived from a Wistar strain; their gestational period averaged 21 days. Tissues were cultured from three separate litters of fetal rats of 15 days' gestation and from a litter of 2-day-old rats. A given tissue was obtained from several rats in the same litter and the tissues were pooled. After the tissues were minced, amounts from 40 to $80 \mathrm{mg}$ were placed in each of three or four roller tubes with $1 \mathrm{ml}$ of Eagle's basal medium with Hank's solution containing $5 \%$ horse serum and $2 \mu \mathrm{c}$ of either glycine-2-14 $\mathrm{C}$ with a specific activity of $1 \mathrm{mc}$ per mmole or L-leucine- ${ }^{14} \mathrm{C}$, uniformly labeled and having a specific activity of $200 \mathrm{mc}$ per mmole. The tubes were incubated for 3 to 5 days at $37^{\circ} \mathrm{C}$, the medium being replaced as needed; at the end of this time, fibroblast proliferation was evident around the liver tissue and around most of the other tissues as well, but grossly and histologically the pieces of liver retained their hepatic appearance. After incubation, the cultures were frozen and thawed twice; the supernatants were collected by centrifugation, dialyzed against distilled water, and lyophilized, and each was then redissolved in $0.1 \mathrm{ml}$ of $0.1 \mathrm{M} \mathrm{NaCl}$.

Portions of the concentrated supernatants from the tissue cultures were mixed with equal volumes of homologous fetal serum for immunoelectrophoresis, using serum from a fetus of 21 weeks' gestation for the human tissues and pooled serum from rat fetuses of 17 days' gestation for the rat tissue cultures; the fetal serum was added as a carrier to assure precipitation of any labeled serum $\alpha$-fetoprotein by antiserum. Immunoelectrophoresis was performed by the method of Scheidegger (18), using an agar concentration of $1.5 \mathrm{~g}$ per $100 \mathrm{ml}$ of $0.1 \mathrm{M}$ borate buffer of $\mathrm{pH}$ 8.6. After development of the electrophoresis slides with antiserum, the slides were washed in three changes of $0.1 \mathrm{M} \mathrm{NaCl}$ over a 2-day period, then dried

\footnotetext{
${ }^{2}$ Grand Island Biological Co., Grand Island, N. Y.
}

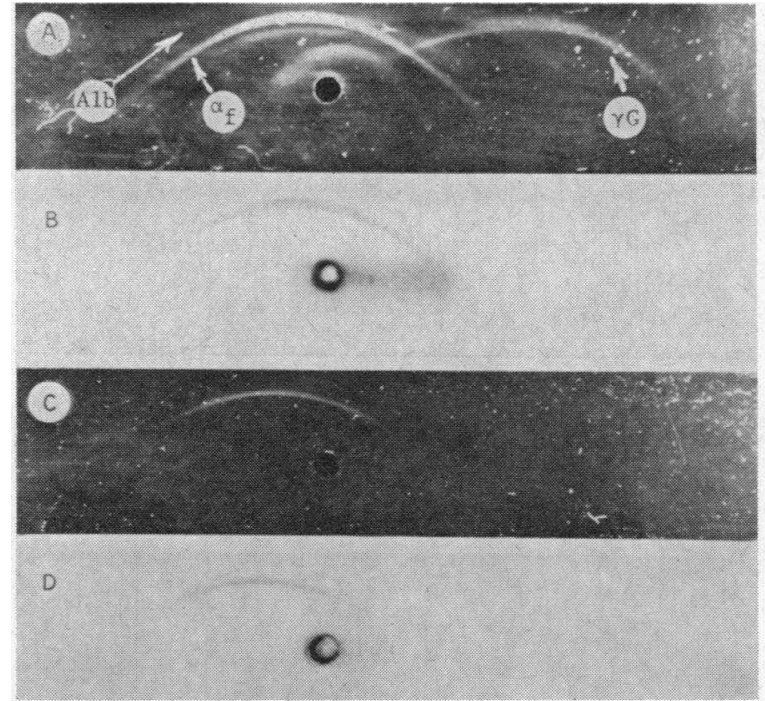

Fig. 1. IMMUNOELECTROPHORESIS OF CULTURE FLUID THAT WAS DIALYZED AND CONCENTRATED AFTER INCUBATION FOR 16 HOURS WITH MINCED LIVER FROM A HUMAN EMBRYO OF 6 WEEKS' GESTATION. Culture fluid contained glycine- $2-{ }^{14} \mathrm{C}$ at onset of incubation and fetal human serum was added as a carrier for immunoelectrophoresis. Anode was to the left and the antisera diffused into the agar from the top of each figure. $A$ ) Precipitation lines obtained by development with unadsorbed antiserum against human fetal serum proteins; the precipitation line for serum albumin is barely discernible, but that for $\alpha$-fetoprotein is clearly observed. B) Radioautograph of immunoelectrophoresis plate in $A . C$ ) Precipitation of $\alpha$-fetoprotein with anti-H $\alpha$. D) Radioautograph of $C$.

and placed on sheets of Tri-X Ortho film ${ }^{3}$ for periods of 10 to 30 days for radioautography.

Portions of the heterologous fetal serum were also mixed with equal volumes of the concentrated tissue culture supernatants: fetal rat serum was mixed with the human tissue culture fluids and the immunoelectrophoretic patterns were developed with antiserum against rat $\alpha$-fetoprotein, while fetal human serum was mixed with an equal volume of the rat tissue culture fluids and immunoelectrophoresis was performed using antiserum against human $\alpha$-fetoprotein for development. Radioautography of the washed and dried slides was carried out on Tri-X Ortho film as above.

Antisera. The antisera against fetal human serum proteins used in the present study were the same as those used earlier (1); when adsorbed with adult human serum, the antisera (anti-H $\alpha$ ) were specific for human $\alpha$-fetoprotein (Figure 1) and did not react with any of the proteins in adult human serum. Antisera against fetal rat serum proteins were prepared in a similar manner; rabbits were injected subcutaneously with $0.03 \mathrm{ml}$ of fetal rat serum emulsified in complete

\footnotetext{
${ }^{3}$ Eastman Kodak, Rochester, N. Y.
} 


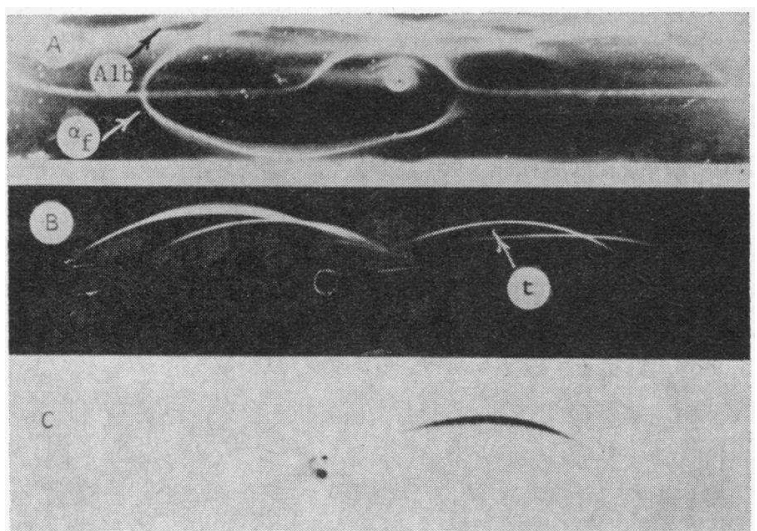

Fig. 2. IMMUNOELECTROPHORESIS OF FETAL HUMAN AND RAT SERUM WITH A RADIOAUTOGRAPH OF THE RAT SERUM. A) Immunoelectrophoresis of fetal human serum; anode was to the left. Unadsorbed antiserum against fetal human serum proteins diffused into agar from the top of the figure; the same antiserum adsorbed with adult human serum, anti- $\mathrm{H} \alpha$, diffused into the agar from the bottom of the figure. The precipitation line for $\alpha$-fetoprotein formed with anti-H $\alpha$ fused (at arrow $\alpha_{\mathbf{f}}$ ) with the same antigen precipitated by the unadsorbed antiserum marked $\alpha_{\mathrm{f}}$ in Figure 1A, proving the latter to be $\alpha$-fetoprotein and not albumin; extension of the other curvilinear bands into precipitation lines parallel to the antiserum wells was due to interaction of the unabsorbed antiserum with maternal serum proteins added to the adsorbed antiserum. B) Immunoelectrophoresis of fetal rat serum containing ${ }^{50} \mathrm{Fe}$ using unadsorbed antiserum. $C$ ) Radioautograph of $B$ indicating that the antigen marked $\mathrm{t}$ in $B$ was transferrin.

Freund's adjuvant, one injection every 2 weeks for eight injections, the serum used as the antigen being from fetuses of 14 days' gestation. When adsorbed with an equal volume of adult rat serum, the antiserum (anti$\mathrm{R} \alpha$ ) retained precipitins for two fetal rat serum proteins (Figure 3 ), one of which was $\alpha$-fetoprotein and the other an $\alpha_{2}$-globulin described by Wise, Ballard, and Ezekiel $(13,15)$; although the adult rat serum used for adsorption contained small amounts of the $\alpha_{2}$-globulin, the amount was insufficient to bind completely the precipitins against this protein under the conditions of the adsorption (15). For purposes of identification in this report, the $\alpha_{2}$-globulin will be termed $R \alpha_{2}$-globulin. Anti-H $\alpha$ and anti-R $\alpha$ were each specific for the homologous $\alpha$-fetoprotein : anti-H $\alpha$ did not precipitate rat $\alpha$-fetoprotein and anti-R $\alpha$ did not precipitate human $\alpha$-fetoprotein.

To identify the precipitation line formed by iron-binding globulin, or transferrin, in the immunoelectrophoretic pattern of fetal rat serum developed by unadsorbed rabbit antisera, we added approximately $0.05 \mu \mathrm{c}$ of ferric citrate as ${ }^{50} \mathrm{Fe}$ to $0.1 \mathrm{ml}$ of fetal rat serum before electrophoresis; after immunoelectrophoresis of this mixture, the slides were washed in $0.1 \mathrm{M} \mathrm{NaCl}$ for 2 days and then dried. Radioautography was carried out using Tri-X Ortho film and an exposure period of 2 days (Figure 2, $\mathrm{B}$ and $\mathrm{C}$ ).

Quantitative serum protein determinations. Concentrations of rat serum $\alpha$-fetoprotein and $R \alpha_{2}$-globulin were estimated in duplicate by the method of Mancini, Carbonara, and Heremans (19). Although two precipitation rings appeared using anti-R $\alpha$, there was no difficulty in differentiating each ring according to the antigen represented; the two rings differed in density and in relative position, and the relative position of each antigen was checked in Ouchterlony plates $(20,21)$ using serum from a fetal rat of 13 days' gestation as the reference antigen in which $\alpha$-fetoprotein was the major antigen and the $\alpha_{2}$-globulin could barely be detected (15). The pooled serum from a litter of fetuses of 19 days' gestation was used as the reference standard for the two proteins; the concentration of $\alpha$-fetoprotein in this serum was estimated by planimetry of cellulose acetate electrophoresis patterns (22) and the determination of total serum protein: the $\alpha$-fetoprotein in this serum as determined by planimetry of four different electrophoretic patterns was $31 \pm 2 \%$ (SE) of the total serum protein, and the total serum protein was $2.6 \pm 0.1 \mathrm{~g}$ (SE) per



Fig. 3. IMMUNOELECTROPHORESIS OF A 5-DAY CULTURE OF FETAL RAT LIVER. The culture fluid contained glycine${ }_{2-}{ }^{14} \mathrm{C}$ and fetal rat serum was added as a carrier for immunoelectrophoresis. Anode was to the left and the antisera diffused into the agar from the top of each figure. $A$ ) Precipitation lines obtained with unadsorbed antiserum against fetal rat serum proteins. $B$ ) Radioautograph of $A$, showing radioactive serum albumin, $\alpha$-fetoprotein, $\mathrm{R} \alpha_{2}$-globulin, transferrin (arrow), and several proteins not readily discerned in $A$. C) Precipitation lines obtained with anti-R $\alpha . D$ ) Radioautograph of $C$, showing radioactive $\alpha$-fetoprotein and $R \alpha_{2}$-globulin. Symbols : $\alpha_{2}=\mathrm{R} \alpha_{2}$-globulin; remainder as in Figure 1. 
$100 \mathrm{ml}$. The values for $\alpha$-fetoprotein are expressed in milligrams per $100 \mathrm{ml}$, but it should be noted that the concentrations of $\alpha$-fetoprotein in the different sera relative to each other are the same as the estimated absolute concentrations are to each other regardless of an error in the determination of $\alpha$-fetoprotein in the reference standard. The concentrations of $\mathrm{R} \alpha_{2}$-globulin are given in terms of the reference standard, which was set at $100 \%$.

\section{Results}

Radioautography of immunoelectrophoresis patterns. Of the human embryonic tissues incubated with amino acids ${ }^{14} \mathrm{C}$, only the liver yielded serum $\alpha$-fetoprotein that was detectably radioactive by this technique (Figure 1), and of the six liver incubations prepared, radioactive serum $\alpha$-fetoprotein was found in five. That the precipitation band $\alpha_{\mathrm{f}}$ obtained with the unadsorbed antiserum against human fetal serum proteins (Figure 1A) was due to precipitation of $\alpha$-fetoprotein is indicated by the fact that the band fused with the precipitation band obtained with the adsorbed antiserum, anti-H $\alpha$, which was specific for $\alpha$-fetopro-



Fig. 4. IMMUNOELECTROPHORESIS OF 4-DAY CULTURE OF RAT FETAL MEMBRANES WITH FETAL RAT SERUM ADDED AS CARRIER. Culture fluid contained glycine-2- ${ }^{14} \mathrm{C}$. Anode was to the left and the antisera diffused into the agar from the bottom of each figure. $A$ ) Precipitation lines obtained with unadsorbed antiserum against fetal rat serum proteins. $B$ ) Radioautograph of $A$, showing radioactive $\alpha$-fetoprotein and transferrin (arrow). $C$ ) Precipitation lines obtained with anti-R $\alpha$. D) Radioautograph of $C$, showing radioactive $\alpha$-fetoprotein.

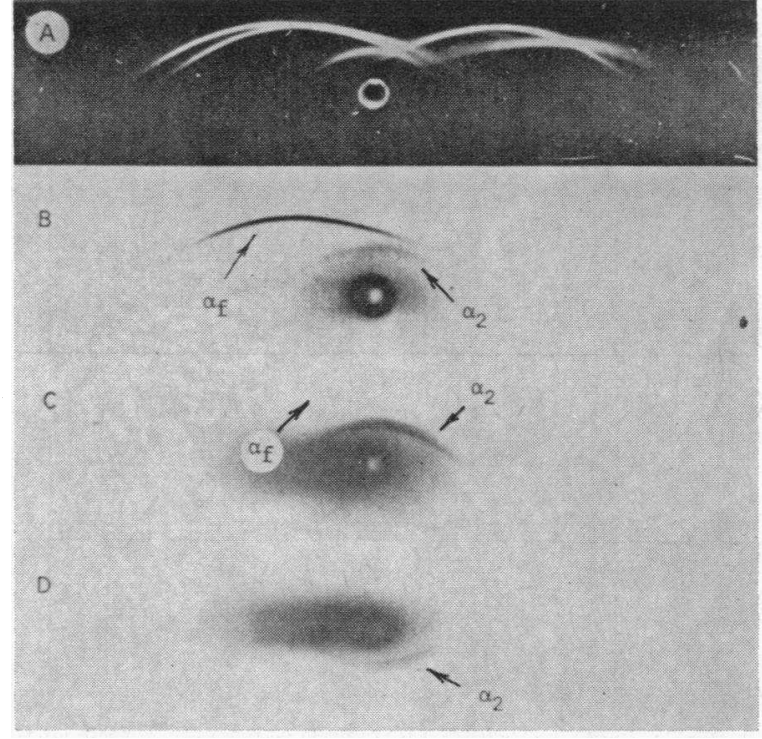

Fig. 5. IMMUNOELECTROPHORESIS OF 4-DAY CULTURES OF RAT PLACENTAS. Fetal rat serum added as carrier. Culture fluids in $A$ and $B$ contained glycine- $2-{ }^{14} \mathrm{C}$; those in $C$ and $D$ contained L-leucine- ${ }^{14} \mathrm{C}$. Anode to the left. Antiserum used for development in each instance was unadsorbed antiserum against fetal rat serum proteins that diffused from the bottom of the figure in $D$ but from the top of each figure in the others. $A$ ) Precipitation lines obtained with culture of placenta including lining of yolk sac. $B)$ Radioautograph of $A$ showing a prominent radioactive $\alpha$-fetoprotein band, $R \alpha_{2}$-globulin, and transferrin. C) Radioautograph of a culture of a placenta with most of the yolk sac removed, showing a prominent line for $R \alpha_{2}$-globulin and a faint line for $\alpha$-fetoprotein. $D$ ) Radioautograph of a culture of a placenta with yolk sac removed, showing only radioactive $R \alpha_{2}$-globulin.

tein (Figure 2A). Cultures of human embryonic skin, skeletal muscle, brain, heart, lung, kidney, stomach, intestines, umbilical cord, and placenta failed to produce detectable radioactive $\alpha$-fetoprotein. Unlabeled rat $\alpha$-fetoprotein added to portions of the human tissue cultures as fetal rat serum and then precipitated with anti-R $\boldsymbol{\alpha}$ on immunoelectrophoresis did not reveal detectable radioactivity on radioautography.

All of the cultures of fetal rat liver and the cultures of liver from the 2-day-old rat contained radioactive serum $\alpha$-fetoprotein, radioactive $R \alpha_{2}$ globulin, radioactive albumin, and several additional radioactive serum proteins (Figure 3 ). Cultures of the rat fetal membranes, which in the rat include the yolk sac, and cultures of the yolk sac alone produced radioactive serum $\alpha$-fetopro- 




Fig. 6. SERUM CONCENTRATIONS OF $\alpha$-FETOPROTEIN AND $R \alpha_{2}$-GLOBULIN IN THE RAT AS A FUNCTION OF AGE.

tein (Figure 4) and an additional radioactive serum protein (Figure 4B) that was shown to be transferrin (Figure 2C); radioactive transferrin was also found in the liver cultures (Figure 3B). Cultures of the rat placenta resulted in the synthesis of radioactive $R \alpha_{2}$-globulin (Figure 5), and in those instances where the fetal membranes were not removed from the fetal side of the placenta, radioactive $\alpha$-fetoprotein and radioactive transferrin were found as well (Figure 5B). Radioactive serum proteins were not detected in cultures of fetal rat lung, heart, kidney, intestines, brain, skeletal muscle, or skin. Unlabeled human $\alpha$-fetoprotein added to portions of the rat tissue cultures, including the liver and yolk sac cultures, as fetal human serum and then precipitated with anti- $\mathrm{H}_{\alpha}$ on immunoelectrophoresis did not show detectable radioactivity on radioautography.

Changes in the serum concentration of $\alpha$-fetoprotein in the developing rat. The serum concentrations of $\alpha$-fetoprotein and $\mathrm{R} \alpha_{2}$-globulin in the normal developing rat from the fourteenth day of gestation to 18 days after birth are shown in Fig- ure 6. The value expressed for a given gestational day represents the average concentration obtained for two to three litters, the serum from all of the fetuses of a single litter being pooled and estimated separately; the number of fetuses per litter varied from nine to thirteen. Each concentration given for the rats postpartum is the average value for at least nine animals representing three different litters, two to four rats being taken from a given litter on each of three to four different days. It will be noted that the serum concentration of $\alpha$-fetoprotein fell abruptly beginning at or close to the time of birth. At 2 days postpartum, the concentration of $\alpha$-fetoprotein was approximately half of that present before birth; the average weight of the rats increased from $5.7 \mathrm{~g}$ at birth to approximately $7.5 \mathrm{~g}$ at 2 days of age, or an increase of $28 \%$. A second decrease in $\alpha$-fetoprotein concentration was evident after 6 to 8 days of age. The changes in the serum concentration of $\mathrm{R}_{2}$-globulin (Figure 6) were quite different from the changes noted for $\alpha$-fetoprotein; the concentration of $\mathrm{R} \alpha_{2}$-globulin increased rapidly from 14 days' gestation until birth, and then after delivery decreased relatively more slowly than did the $\alpha$-fetoprotein level.

\section{Discussion}

Simple binding of radioactive amino acids to $\alpha$-fetoprotein sufficient to account for the radioautography findings, or to any of the other serum proteins found to be radioactive in this study, seems unlikely, since cultures of those tissues that did not yield radioactive serum proteins contained the same amino acids ${ }^{14} \mathrm{C}$ as those tissues that did, and immunoelectrophoresis was performed with the same homologous fetal serum as a carrier. It is possible that the liver or yolk sac or both might have a specific capacity to synthesize a radioactive compound from amino acids $-{ }^{14} \mathrm{C}$ that might be bound specifically by $\alpha$-fetoprotein; whether any such substances are manufactured by these organs is not known, but to explain the results of radioautography, a) synthesis of such a compound would have to be restricted to one or both organs, since the other tissue cultures did not yield radioactive $\alpha$-fetoprotein; $b$ ) the hypothetical substance, if synthesized by the rat yolk sac at least, would have to be relatively specific 
for $\alpha$-fetoprotein, and possibly transferrin, since none of the other fetal serum proteins precipitated by the unadsorbed antirat antisera were radioactive in the yolk sac cultures; c) any such compound synthesized by either human liver, rat liver, or rat yolk sac must either be specific for the $\alpha$-fetoprotein of the species or once bound is not exchanged, since the addition of carrier fetal rat serum to human liver cultures followed by immunoelectrophoresis using anti-R $\boldsymbol{\alpha}$ for development failed to reveal any radioactive rat $\alpha$-fetoprotein, and the addition of carrier fetal human serum to the rat tissue cultures followed by immunoelectrophoresis and development with anti$\mathrm{H} \boldsymbol{\alpha}$ likewise failed to reveal radioactive human $\alpha$-fetoprotein. It would seem unlikely, therefore, that the radioactivity associated with $\alpha$-fetoprotein as determined by radioautography was due entirely to simple binding of a radioactive compound. The data suggest that the liver may be a source of serum $\alpha$-fetoprotein synthesis in the human embryo, and that the liver and the yolk sac both may synthesize $\alpha$-fetoprotein in the fetal rat; since the human yolk sac was not studied, it is not known whether this tissue might also synthesize $\alpha$-fetoprotein. The initial, relatively abrupt decline in $\alpha$-fetoprotein concentration in the rat that was evident beginning immediately after birth is in accord with the observation that $\alpha$-fetoprotein may be synthesized by the yolk sac, since the latter structure is, of course, discarded after delivery. The fall in $\alpha$-fetoprotein level apparently was not due simply to an increase in the size of the newborn rat during this period, in view of the fact that relative growth was much smaller than the relative decrease in $\alpha$-fetoprotein concentration. The fall also would not appear to be due to redistribution of serum $\alpha$-fetoprotein after delivery, since labeled $\gamma \mathrm{G}$-globulins passed to the rat fetus from the mother diaplacentally disappear from the serum as single exponentials for at least a week after birth, suggesting that large abrupt net shifts of protein from the plasma immediately after birth probably do not occur (23).

It is interesting to note that the yolk sac in the rat apparently contributes still another protein to the serum besides $\alpha$-fetoprotein, transferrin, which also seems to be synthesized by the liver of the 2-day-old rat as well as by the liver of the fetal animal, and that the placenta, like the liver, ap- pears to synthesize the serum protein designated as $R \alpha_{2}$-globulin. The absence of a radioactive precipitation band for albumin in the cultures of human liver (Figure 1B) should not be interpreted to indicate that the liver of the 2.0- to 4.3$\mathrm{cm}$ human embryo does not synthesize albumin; the precipitation band resulting from the interaction of albumin with the unadsorbed antiserum against human fetal serum proteins was barely detectable in these immunoelectrophoresis slides as can be seen in Figure 1A, due to the relatively low concentration of specific antibodies for albumin in these antisera, and due to the fact that the albumin precipitation band became increasingly more diffuse and migrated into the antiserum well during the 2 to 3 days allowed for the precipitation of $\alpha$-fetoprotein.

\section{References}

1. Gitlin, D., and M. Boesman. Serum $\alpha$-fetoprotein, albumin, and $\gamma \mathrm{G}$-globulin in the human conceptus. J. clin. Invest. 1966, 45, 1826.

2. Bergstrand, C. G., and B. Czar. Demonstration of a new protein fraction in serum from the human fetus. Scand. J. clin. Lab. Invest. 1956, 8, 174.

3. Bergstrand, C. G., and B. Czar. Paper electrophoretic study of human fetal serum proteins with demonstration of a new protein fraction. Scand. J. clin. Lab. Invest. 1957, 9, 277.

4. Halbrecht, I., C. Klibanski, H. Brzoza, and M. Lahav. Further studies on the various hemoglobins and the serum protein fractions in early embryonic life. Amer. J. clin. Path. 1958, 29, 340.

5. Halbrecht, I. Clinical significance of the fetal and embryonic hemoglobins and of the embryonic serum protein fraction. Harefuah 1959, 57, 267.

6. De Muralt, G., and D. L. A. Roulet. Etude immunologique des protéines sériques foetales humaines. Helv. paediat. Acta 1961, 16, 517.

7. Galdo, A., J.-P. Casado, and R. Talavera. Démonstration dans le sérum du foetus humain d'une nouvelle fraction protéique au moyen de l'électrophorèse sur papier. Arch. franç Pédiat. 1959, 16, 954.

8. Andreoli, M., and J. Robbins. Serum proteins and thyroxine-protein interaction in early human fetuses. J. clin. Invest. 1962, 41, 1070.

9. Bodman, J. Development of foetal proteins. Clin. chim. Acta 1959, 4, 103.

10. Masopust, J., and L. Kotál. Fetoprotein: immunochemical behavior of an autonomous fetal component in sera from human fetuses. Ann. paediat. (Basel) 1965, 204, 138.

11. Tatarinov, Y. S. New data on the embryo-specific antigenic components of human blood serum. Vop. med. Khim. 1964, 10, 584. 
12. Shmerling, Z. G., and V. D. Uspenskaya. Embryonic blood serum proteins in rats and rabbits. Biokhimiia 1955, 20, 31.

13. Wise, R. W., F. J. Ballard, and E. Ezekiel. Developmental changes in the plasma protein pattern of the rat. Comp. Biochem. Physiol. 1963, 9, 23.

14. Tatarinov, Y. S., and A. V. Afanasyeva. The detection of similar antigenic determinants in embryospecific alpha-globulin of man and certain animals. Biull. exp. Biol. Med. 1965, 59, 65.

15. Gitlin, D., and M. Boesman. Fetus-specific serum proteins in several mammals and their relation to human $\alpha$-fetoprotein. Comp. Biochem. Physiol. In press.

16. Streeter, G. L. Developmental horizons in human embryos. Carnegie Cont. Emb. 1948, 32, 133.

17. Patten, B. M. Human Embryology. New York, Blakiston, 1953.
18. Scheidegger, J. J. Une micro-méthode de l'immunoélectrophorèse. Int. Arch. Allergy 1955, 7, 103.

19. Mancini, G., A. O. Carbonara, and J. F. Heremans Immunochemical quantitation of antigens by single radial immunodiffusion. Int. J. Immunochemistry 1965, 2, 235.

20. Ouchterlony, Ö. Antigen-antibody reactions in gels. IV. Types of reactions in coordinated systems of diffusion. Acta path. microbiol. scand. 1953, 32, 231.

21. Crowle, A. J. A simplified micro double-diffusion agar precipitin technique. J. Lab. clin. Med. 1958, 52, 784.

22. Grunbaum, B. W., M. F. Lyons, N. V. Carroll, and J. Zec. Quantitative analysis of normal human serum proteins on permanently transparentized cellulose acetate membranes. Microchem. J. 1963, 7, 54.

23. Koch, C., and D. Gitlin. Unpublished data. 